\title{
LACK OF SPECIFICITY OF THE MOLECULAR DIAGNOSTIC METHOD FOR IDENTIFICATION OF APHANOMYCES ASTACI
}

\author{
I. BALLESTEROS (1), M.P. MARTíN (1), L. CERENIUS (2), K. SÖDERHÄLL (2), M.T. \\ TELLERÍA (1), AND J. DIÉGUEZ-URIBEONDO (1*)
}

(1) Departamento de Micología, CSIC, Real Jardín Botánico, Plaza Murillo 2, 28014 Madrid, Spain.

(2) Department of Comparative Physiology, Uppsala University, Norbyvägen 18A, S-752 36 Uppsala, Sweden.

$\left({ }^{*}\right)$ Corresponding author. Departamento de Micología, CSIC, Real Jardín Botánico, Plaza Murillo 2, 28014 Madrid, Spain, Phone: +34-91-4203017; Fax: +34-91-4200157. E-Mail : dieguez@rjb.csic.es

Reçu le 7 décembre 2006

Accepté le 15 mai 2007

Received December 7, 2006

Accepted May 15, 2007

\section{ABSTRACT}

A recent PCR-test developed for identification of Aphanomyces astaci, the organism responsible for crayfish plague, provided false positives for Aphanomyces frigidophilus, Aphanomyces repetans, and some Saprolegnia spp. Real-time PCR showed that with the designed primers, $A$. astaci and $A$. frigidophilus cannot be distinguished. The results of this study show that this particular crayfish plague PCR-test ought to be improved and that molecular-based techniques need to be contrasted to histological evidences and disease history.

Key-words: Oomycetes, crayfish plague, ITS, crayfish, Conservation, invasive species.

\section{MANQUE DE SPÉCIFITÉ DE LA MÉTHODE DE DIAGNOSTIC MOLÉCULAIRE POUR L'IDENTIFICATION D'APHANOMYCES ASTACI}

\section{RÉSUMÉ}

Un test PCR récemment développé pour identifier Aphanomyces astaci, organisme responsable de la peste de l'écrevisse, a donné des faux positifs pour Aphanomyces frigidophilus, Aphanomyces repetans, et pour quelques Saprolegnia spp. La PCR en temps réel montre, qu'avec les "primers" redessinés, $A$. astaci et $A$. frigidophilus ne peuvent pas être distingués. Les résultats de cette étude montrent que ce test $\mathrm{PCR}$, conçu pour identifier la peste de l'écrevisse, doit être amélioré et que les techniques moléculaires doivent être confortées par des évidences histologiques et en fonction de l'histoire de la maladie. invasives.

Mots-clés : Oomycètes, peste de l'écrevisse, ITS, écrevisse, conservation, espèces 


\section{INTRODUCTION}

The heterokont Aphanomyces astaci (Saprolegniales, Oomycetes) is responsible for the crayfish plague and is amongst the 100 worst invasive species (DIÉGUEZ-URIBEONDO et al., 2006). This organism devastated the indigenous European crayfish and represents a threat for the Australasian crayfish species (UNESTAM, 1972). Recent molecular diagnosis method based on species-specific PCR primers for ITS sequences (OIDTMANN et al., 2004) has allowed approaching the diagnosis of crayfish plague on clinical samples without carrying out tedious isolations and virulence experiments (CERENIUS et al., 1988). However, this test has been only applied to a limited number of Aphanomyces species. Two new Aphanomyces species were recently isolated from crayfish and crayfish plague cases i.e. Aphanomyces frigidophilus (BALLESTEROS et al., 2006; KITANCHAROEN and HATAI, 1997), and $A$. repetans (ROYO et al., 2004). The objective of this study was to confront the existing crayfish plague PCR-diagnostic test to recently described Aphanomyces species, and to evaluate the specificity of the primers designed by using real-time PCR. Realtime PCR allow detection of PCR amplification during the early phases of the reaction, and therefore quantify the degree of specificity for primers, which represents a distinct advantage over traditional PCR detection (LIVAK et al., 1995).

\section{MATERIALS AND METHODS}

To test the application of this method both clinical samples and pure cultures of isolates were used. Clinical samples consisted of cuticles preserved in $70 \%$ ethanol from crayfish plague cases that occurred in Spain during 2004 and 2005. Sample 1, was from a crayfish plague-like case from which $A$. frigidophilus was isolated (BALLESTEROS et al., 2006). Samples 2 and 4, belonged to crayfish plague cases, and sample 3, were from Saprolegnia parasitica infected crayfish. Pure cultures of isolates of $A$. frigidophilus SAP233, A. repetans SAP60, A. astaci strains L1, Kv1 and T1, S. parasitica SAP210, Saprolegnia australis SAP211 were used in the experiments. Pure cultures were grown as drop cultures (CERENIUS and SÖDERHÄLL, 1985), and genomic DNA was extracted using an E.Z.N.A.Fungi DNA miniprepkit kit (Omega Biotek, Doraville, GA). For cuticle samples, total genomic DNA was extracted using a DNeasy kit for animal tissue (Qiagen, Valencia, CA). Genomic DNA was amplified with primers 525 and 640 as described in (OIDTMANN et al., 2004) based on the ITS region surrounding the 5.8S rDNA gene from $A$. astaci strain FDL 457 (OIDTMANN et al., 2004). PCR amplifications were carried out using PCR Beads (Amersham Biosciences, Piscataway, $\mathrm{NJ}$ ) in $25 \mu \mathrm{l}$ containing $0.4 \mu \mathrm{M}$ of each primer and $150 \mathrm{ng}$ of pure culture DNA and $1 \mu \mathrm{g}$ of infected cuticle DNA. Cycling conditions were as described by (OIDTMANN et al., 2004). Amplified products were detected by $2 \%$ agarose gel electrophoresis in TE buffer, stained with ethidium bromide and visualized under UV light. Real-time PCR was performed in a LigthCycler (Roche Molecular Biochemicals, Indianapolis, IN). In each capillary, $20 \mu \mathrm{l}$ reactions were pipetted. The reactions contained $2 \mu \mathrm{LNA}$ template, $1 \mu \mathrm{M}$ of each primer (525 and 640), $2 \mu \mathrm{l}$ of the SYBR Green PCR Master Mix (Roche Molecular Biochemicals), $2.4 \mu \mathrm{l}$ of $25 \mathrm{mM} \mathrm{MgCl}_{2}$ and $11.6 \mu \mathrm{l}$ of sterile water provided by the manufacturer. After a preincubation stage of $95^{\circ} \mathrm{C}$ for $30 \mathrm{~s}$, amplifications were performed for 25 cycles of $95^{\circ} \mathrm{C}$ for $10 \mathrm{~s}, 52^{\circ} \mathrm{C}$ for $5 \mathrm{~s}, 62^{\circ} \mathrm{C}$ for $5 \mathrm{~s}$ and $72^{\circ} \mathrm{C}$ for $10 \mathrm{~s}$. After amplification, a melting curve was generated by holding the reaction at $65^{\circ} \mathrm{C}$ for $15 \mathrm{~s}$, and then heating to $95^{\circ} \mathrm{C}$ with a ramp rate of $0.1^{\circ} \mathrm{C} . \mathrm{s}^{-1}$. To assign a melting temperature for each sample, the fluorescence signal was plotted against temperature. Aliquots of some DNA templates were used to repeat the assays in the ABI Prism ${ }^{\circledR} 7700$ Sequence Detection System (Applied Biosystems, Foster City, CA). In each well, $25 \mu \mathrm{l}$ reactions were pipetted containing $3 \mu$ l of DNA template, $0.2 \mu \mathrm{M}$ of each primer, $12.5 \mu \mathrm{l}$ of the SYBR $®$ Green PCR Master Mix (Applied Biosystems) and $8.5 \mu \mathrm{l}$ of sterile Milli-Q water. Controls, DNA-free, were run for each experiment. Amplification conditions were: (a) incubation step at $95^{\circ} \mathrm{C}$ for $10 \mathrm{~min}$; (b) DNA amplification for 40 cycles of $95^{\circ} \mathrm{C}$ for $15 \mathrm{~s}, 55^{\circ} \mathrm{C}$ for $30 \mathrm{~s}$ and $72^{\circ} \mathrm{C}$ for $30 \mathrm{~s}$. A melting curve temperature profile was obtained by $95^{\circ} \mathrm{C}$ for $1 \mathrm{~min}, 60^{\circ} \mathrm{C}$ for $1 \mathrm{~min}$ and heating to $95^{\circ} \mathrm{C}$ in $20 \mathrm{~min}$. Data were analyzed using the software version SDS 1.9.1 and Dissociation Curves 1.0. (Applied Biosystems) 


\section{RESULTS AND DISCUSSION}

From both diagnostic samples infected with A. frigidophilus or S. parasitica (Figure 1A), and in pure cultures from all Aphanomyces and Saprolegnia species tested, amplicons of the same length as for $A$. astaci were obtained. Similar results were obtained after increasing annealing temperature and reducing the number of cycles (Figure 1B). Because the species $A$. frigidophilus and $A$. repetans, occur in crayfish species (BALLESTEROS et al., 2006; ROYO et al., 2004), and Saprolegnia spp. are ubiquitous with a worldwide and distribution, a great number of false positive is expected when applying the primers used in current crayfish plague PCR-test.
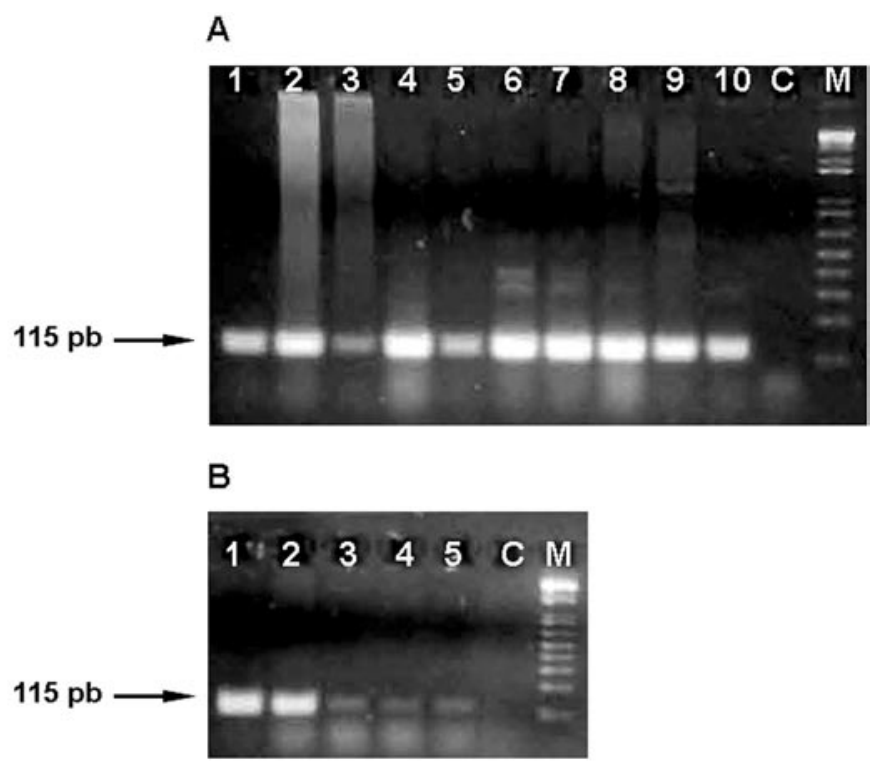

Figure 1

PCR products from cuticle samples and pure cultures.

(A) DNA amplification using an annealing temperature of $54^{\circ} \mathrm{C}$.

Lane 1: cuticle from where Aphanomyces frigidophilus was isolated; lane 2: cuticle infected with Aphanomyces astaci; lane 3: cuticle infected with Saprolegnia parasitica, lane 4: A. frigidophilus SAP233; lane 5: Aphanomyces repetans SAP60; lane 6: $A$. astaci L1; lane 7: $A$. astaci Kv1; lane 8: A. astaci Ti1; lane 9: S. parasitica SAP210; lane 10: Saprolegnia australis SAP211; lane C: DNA-free control; M: 100pb marker.

(B) DNA amplification using an annealing temperature of $58^{\circ} \mathrm{C}$.

Lane 1: A. astaci Ti1; lane 2: A. frigidophilus SAP233; lane 3: $A$. repetans SAP60; lane 4: S. parasitica SAP210; lane 5: S. australis SAP211.

Figure 1

Produits PCR à partir d'échantillons de cuticule et de cultures pures. (A) Amplification de I'ADN utilisant une température d'annealing de $54^{\circ} \mathrm{C}$.

Ligne 1 : cuticule à partir de laquelle Aphanomyces frigidophilus a été isolée ; ligne 2 : cuticule infectée par Aphanomyces astaci ; ligne 3 : cuticule infectée par Saprolegnia parasitica ; ligne 4 : A. frigidophilus SAP233 ; ligne 5 : Aphanomyces repetans SAP60; ligne $6: A$. astaci L1; ligne $7:$ A. astaci Kv1; ligne 8 : A. astaci Ti1 ; ligne 9 : S. parasitica SAP210 ; ligne 10 : Saprolegnia australis SAP211; ligne $C$ : contrôle sans ADN ; $M$ : marqueur 100-pb.

(B) Amplification de l'ADN utilisant une température d'annealing de $58^{\circ} \mathrm{C}$. Ligne 1: A. astaci Ti1 ; ligne 2 : A. frigidophilus SAP233 ; ligne 3 : A. repetans SAP60 ; ligne 4 : S. parasitica SAP210 ; ligne 5 : S. australis SAP211. 
However, with real-time PCR a strong fluorescence signal was detected in DNA amplified from clinical samples infected with $A$. frigidophilus and $A$. astaci, but not in the sample infected with $S$. parasitica (Figure 2). In pure cultures, amplification signal was detected for the three $A$. astaci isolates tested (Ti, Kv1 and L1) and for A. frigidophilus. However, only a weak signal was obtained with DNA from $A$. repetans and S. parasitica (Figure 3). Both species, $A$. frigidophilus and $A$. astaci have a high ITS sequence similarity (BALLESTEROS et al., 2006) and, therefore, the target fragment amplified with this test only differed in 8 out of 115 nucleotides (Figure 4). Thus, the application of real time PCR using these primers to distinguish $A$. astaci from closely related $A$. frigidophilus, appears to be difficult because: (a) the nucleotide variation in the target sequences is not sufficient to discriminate the melting peaks of these two species, since they only differ in $0.5^{\circ} \mathrm{C}$; (b) in clinical samples, the high efficiency of amplification in $A$. astaci can be reduced by the presence of other Aphanomyces species in the same sample, and the amplification signal modify the melting peak.

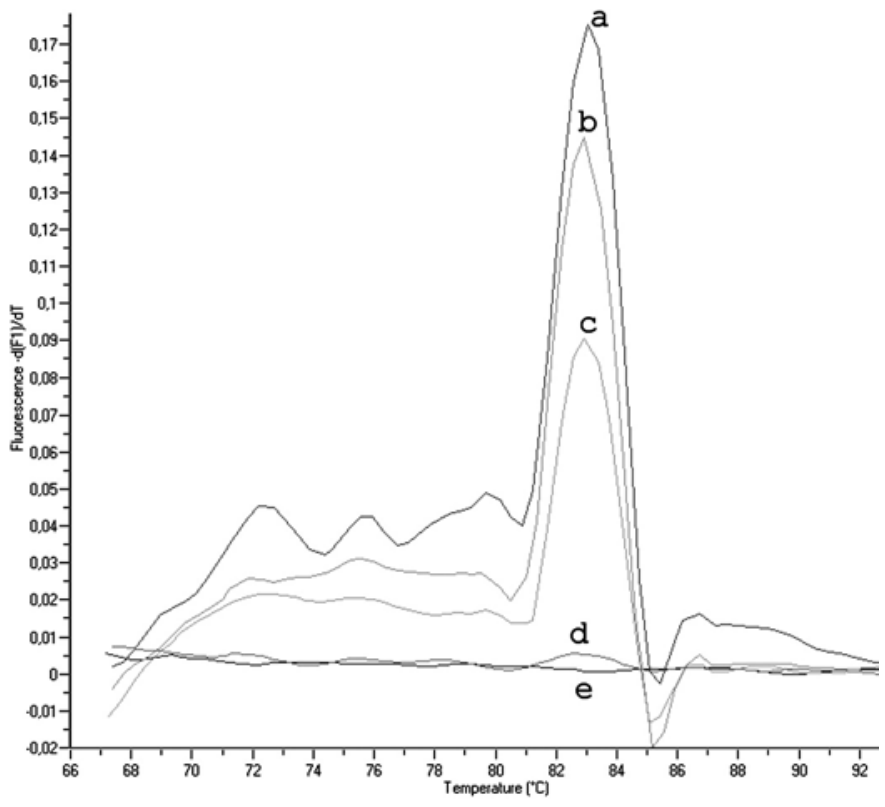

Figure 2

Real-time PCR melting curves for cuticle samples. (a and b), cuticles from infected with Aphanomyces astaci from two crayfish plague cases; (c), cuticle from where Aphanomyces frigidophilus was isolated; (d), cuticle infected with Saprolegnia parasitica; and (e) DNA-free control. Melting shows a single peak around $82.6^{\circ} \mathrm{C}$.

Figure 2

Courbes de PCR en temps réel pour des échantillons de cuticule. (a et b), cuticules infectées avec Aphanomyces astaci à partir de deux cas de peste ; (c), cuticule à partir de laquelle Aphanomyces frigidophilus a été isolée ; (d), cuticule infectée avec Saprolegnia parasitica ; et (e) contrôle sans ADN. Le point de fusion correspond à un pic unique d'environ $82,6^{\circ} \mathrm{C}$. 


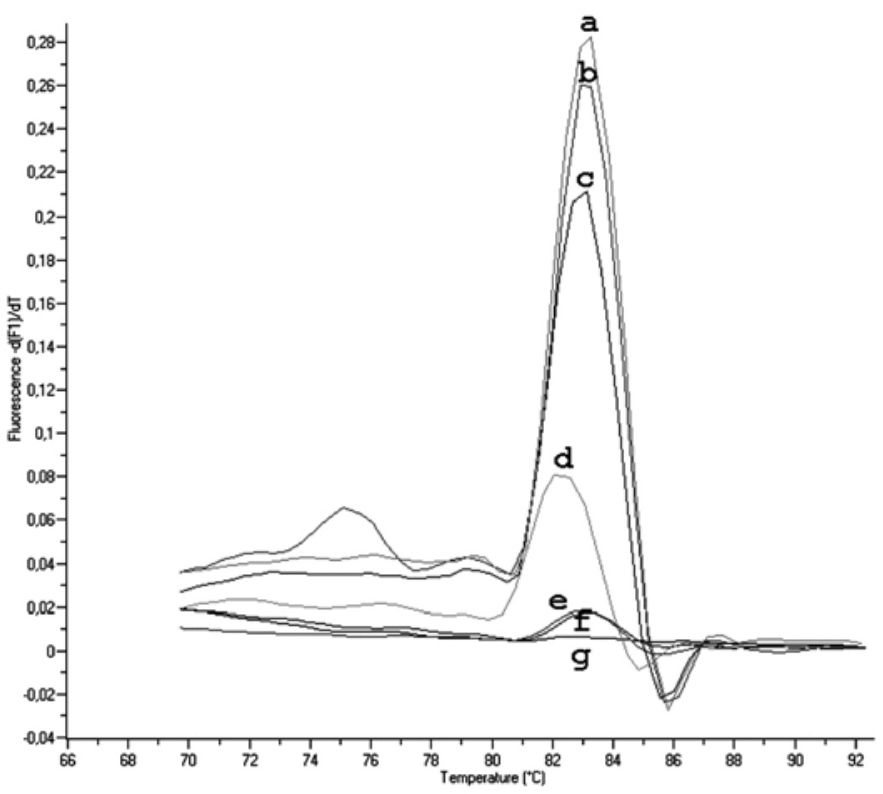

Figure 3

Real-time PCR melting curves for pure cultures. (a), Aphanomyces astaci Kv1; (b), A. astaci L1; (c), A. astaci Ti1; (d), Aphanomyces frigidophilus SAP233; (e), Aphanomyces repetans SAP60; (f), Saprolegnia parasitica SAP210; and (g), DNAfree control. Melting shows a peak at $82.4^{\circ} \mathrm{C}$ for $A$. frigidophilus and at $83.2^{\circ} \mathrm{C}$ for A. astaci strains.

Figure 3

Courbes de PCR en temps réel pour des cultures pures. (a), Aphanomyces astaci Kv1 ; (b), A. astaci L1 ; (c), A. astaci Ti1 ; (d), Aphanomyces frigidophilus SAP233 ; (e), Aphanomyces repetans SAP60 ; (f), Saprolegnia parasitica SAP210 ; et (g), contrôle sans $A D N$. Le point de fusion correspond à un pic de $82,4^{\circ} \mathrm{C}$ pour A. frigidophilus et de $83,2^{\circ} \mathrm{C}$ pour les souches d'A. astaci.

Primer 525

A. astaci $\mathrm{Li}$ : AAGAAGGCTAAATTGCGGTAGTTTTGCTTGTGTTTCGGCACGGGTGAACAACATATTGCT : 60

A. frigid. : AGGAAGGATAAATTGCGGTAGTTTTGCTTGTGTTTCGGCACGGGTGAACAACATATTGCT : 60

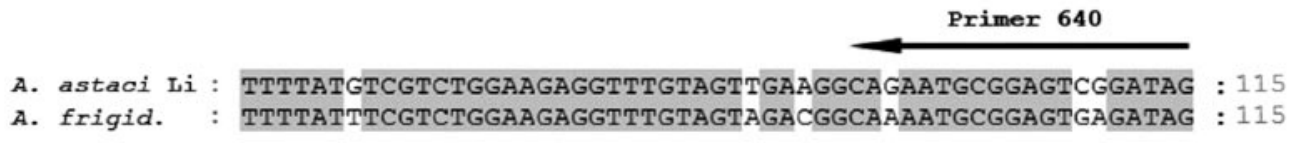

Figure 4

Alignment of the sequence amplified from Aphanomyces astaci and Aphanomyces frigidophilus showing the location of primers 525 and 640. Nucleotides matching the sequence are shaded.

Figure 4

Alignement de la séquence amplifiée à partir d'Aphanomyces astaci et d'Aphanomyces frigidophilus montrant l'emplacement des primers 525 et 640 . Les nucléotides correspondant à la séquence sont ombrés. 
Thus, to accurately identify the presence of $A$. astaci, it is necessary to carry out new approaches based on other sequences of ITS regions or other genes. A PCR-based test for $A$. invadans was successfully and allowed distinguishing this species from $A$. astaci and $A$. frigidophilus (VANDERSEA et al., 2006). In $A$. astaci, a new PCR-based method has been recently developed to detect this parasite in North American crayfish (OIDTMANN et al., 2006). New primers were designed to specifically amplify parts of the internal transcribed spacer (ITS) regions and the 5.8 rRNA gene of $A$. astaci and its specificity was tested against several closely related Aphanomyces species, that might be found in or on crayfish. However, the recent increase of studies on ITS sequence of Oomycetes species shown the existence of new Aphanomyces ITS sequences, probably representing new Aphanomyces spp. and, some of which are closely related to $A$. astaci (Diéguez Uribeondo and Kozubikova, unpublished) that need to be Aphanomyces characterized.

Thus, on the light of the results presented and the new few studies carried out on the diversity of Aphanomyces spp., our results emphasized the need of always contrasting molecular data with classical microscopy evidences and disease history (CERENIUS et al., 1988) in order to confirm the presence of $A$. astaci. Development of a more accurate molecular technique and characterization of new Aphanomyces spp. will facilitate a more accurate and rapid identification of the presence of this parasite in diagnostic samples, water, or potential vectors, which is crucial to implement appropriate management measures for the endangered indigenous European species of crayfish.

\section{ACKNOWLEDGEMENTS}

This work was supported by grants Flora Micológica Ibérica (REN2002-04068C02-01GLO), Carl Tryggers Stiftelse and Swedish Research Council for Environmental, Agriculture Sciences and Spatial Planning (FORMAS). We thank Dr. Pilar San Pio and Dr. Catherine Souty-Grosset for revising the French text.

\section{REFERENCES}

BALLESTEROS I., MARTÍN M.P., DIÉGUEZ-URIBEONDO J., 2006. First isolation of Aphanomyces frigidophilus (Saprolegniales) in Europe. Mycotaxon, 95, 335-340.

CERENIUS L., SÖDERHÄLL K., 1985. Repeated zoospore emergence as possible adaptation to parasitism in Aphanomyces. Exp. Mycol., 9, 259-263.

CERENIUS L., SÖDERHÄLL K., PERSSON M., AJAXON R., 1988. The crayfish plague fungus, Aphanomyces astaci - diagnosis, isolation, and pathobiology. Freshwater Crayfish, 7,131-144.

KITANCHAROEN N., HATAI K., 1997. Aphanomyces frigidophilus sp. nov. from eggs of Japanese char, Salvelinus leucomaenis. Mycoscience, 38,135-140.

DIÉGUEZ-URIBEONDO J., CERENIUS L., DYKOVA I., GELDER S.R., HENTONEN P., JIRAVANICHOAISAL P., LOM J., SÖDERHÄLL K., 2006. Pathogens, parasites and ectocommensals, p. 133-155. In: C. SOUTY-GROSSET, D.M. HOLDICH, P.Y. NOËL, J. D. REYNOLDS, P. HAFFNER (eds.), Atlas of European Crayfish Distribution and Diseases, Museum National d'Histoire Naturelle, Paris, Collection Patrimoines Naturels.

LIVAK K.J., FLOOD S.J., MARMARO J., GIUSTI W., DEETZ K., 1995. Oligonucleotides with fluorescent dyes at opposite ends provide a quenched probe system useful for detecting PCR product and nucleic acid hybridization. PCR Methods Appl., 4, 357-62. 
OIDTMANN B., SCHAEFER N., CERENIUS L., SÖDERHÄLL K., HOFFMANN R.W., 2004. Detection of genomic DNA of the crayfish plague fungus Aphanomyces astaci (Oomycetes) in clinical samples by PCR. Vet. Microbiol., 100, 269-282.

OIDTMANN B., GEIGER S., STEINBAUER P., CULAS A., HOFFMANN RW., 2006. Detection of Aphanomyces astaci in North American crayfish by polymerase chain reaction. Diseases of Aquatic Organisms, 72, 53-64.

ROYO F., ANDERSSON M.G., BANGYEEKHUN E., MÚZQUIZ J.L., SÖDERHÄLL K., CERENIUS L., 2004. Physiological and genetic characterisation of some new Aphanomyces strains isolated from freshwater crayfish. $V$ et. Microbiol., 104, 103112.

UNESTAM T., 1972. On the host range and origin of the crayfish plague fungus. Rep. Inst. Freshwater Res., Drottningholm, 5, 19-8.

VANDERSEA M.W., LITAKER R.W., YONNISH B., SOSA E., LANDSBERG J.H., PULLINGER C., MOON-BUTZIN P., GREEN J., MORRIS J.A., KATOR H., NOGA E.J., TESTER P.A., 2006. Molecular assays for detecting Aphanomyces invadans in ulcerative mycotic fish lesions Appl. Environ. Microbiol., 72, 1551-1557. 
